Valóságos könyvtár - könyvtári valóság. Könyvtár- és információtudományi tanulmányok 2018. Szerk. Kiszl Péter, Csík Tibor.

Budapest, ELTE BTK Könyvtár- és Információtudományi Intézet. 2018. 43-50.

\title{
TUDOMÁNY, TUDÁS - SZEREP ÉS TEVÉKENYSÉG
}

\section{FEHÉR MIKLÓS}

Országos Széchényi Könyvtár Könyvtári Intézet, igazgató

\section{TARTALMI ÖSSZEFOGLALÓ}

A könyvtárosok szenzorként múködnek. Gyüjtik, rendszerezik és trendekké szervezik az információkat. Teszik ezt azért, mert a bölcsesség a jövőbelátás képessége, a jövő pedig a trendekben van megírva, a trendek pedig a szenzorok által rögzített adatokból, információkból állíthatóak fel. De szüksége lesz-e még a világnak a könyvtárosokra - mint szenzorokra -, ha ezt a szerepet a valóságos szenzorok valóságos milliói fogják betölteni, teszi fel a kérdést a szerző, és a választ a könyvekben keresi. Utal a Bibliára, mint egyetemleges útmutatásra, mely alapján az emberközpontú tudomány és a könyvtárosság értelme sem lehet más, mint a boldogság szolgálata. A boldogság átadható. Minden társadalomnak szüksége van boldog emberekre! A könyvtárosság legalapvetőbb küldetése a kulturális és tudományos kincsekben a boldogság megélése és átadása. A mechanikai szenzorok sem megélni, sem átadni nem tudják a boldogságot. Ez az a trend, amely a könyvtárosság jövőjét és szükségességét alátámasztja. A szerző ezt követően Mikszáth Kálmánt, a magyar prózairodalom óriásának egy novelláját idézi, melynek története az emberi tudás és a tudományosság relációját mutatja be. Végezetül a cikk szól a Könyvtári Intézet új cselekvési tervéről, mely a külső partnerek elvárásai alapján fogalmazódott meg. Az Intézet azon tevékenységek végzését preferálja, melyek abban segítik a könyvtárosokat, hogy a könyvtárat „boldogság ház"-ként múködtethessék a felhasználók örömére.

Jómagam, nem lévén tudós ember, sokkal inkább a konferencia előadásait élvezni érkeztem (s teszem ezt, tisztelettel meghajtván magamat mindnyájuk előtt), mintsem bárki elől is elvegyem a szót, a lehetőséget, hogy tudományos gondosságú megfigyeléseit megoszthassa velünk. Mert csuda dolgok rejtekeznek el a megfigyelések mögött. Aki nem tud megfigyelni, rá is fogható mindjárt, nem lesz ám, tudós sohasem. De többet is kell a licitre tennünk: még jó szakmunkássá sem válhat, hiszen ott pláne alfája és ómegája a sikerességnek a megfigyelés, meg aztán az erre épülő utánzás, a másolás, de nem ám az akármilyen, hanem az ügyes kezú másolás készsége.

Amivel persze, valamikor még mindnyájan rendelkeztünk. Olyannyira és oly sikeresen, hogy a születésünket követő néhány hónap, egy-két év múlva már utánozzuk szüleink nyelvét, szavait, gesztusait, gondolkodását, érzelmeit. Kreativitásunknak ekkor még semmi sem szab határt, a rejtett lelki dolgok megértése sem. A pici gyermek ebben sokszor ,jobb”, mint a tanult felnőttek.

„Dörömbös felhő”, mondja kicsi unokahúgom arra az égi jelenségre, amiből nemcsak eső esik, hanem villám is szóródik rettenetes robajjal. S mennyire igaza van. S a fiam 


\section{FEHÉr MiKLÓs}

szerint, aki négyévesen ismerte tízig a számokat, kitalálta, ha van a gépjármúvön rendszám, akkor kell lennie „rendbetû”-nek is, mert a rendszám számokból és betűkből áll. Meg is kért hát engem, - a betűket még nem ismervén - olvassam már el, hogy ennek a kocsinak mi a rendbetúje? S mivel nagy autókedvelő volt, gyakran játszott kedvenc nyergesvontatójával, tologatván maga előtt a földön. És amikor rákérdeztem, mivel játszadozol, a legtermészetesebben mondta: kamiteóval. A kamion és a teherautó ötvözete.

Mégis, mi történik velünk, mikorra megokosodunk? Tekintve az okosságot a felnőtté válás szinonimájának. Mi történik velünk, hogy elfelejtjük a legalapvetőbb dolgokat? Hogy mire felnövünk, elfelejtünk megfigyelni, elfelejtünk megfigyelés alapján utánozni. Ráhagyjuk a látásunkat mások szemére, hallásunkat mások fülére. Reggel nem annak megfelelően öltözködünk, hogy milyen időt látunk odakint a szabadban, hanem, hogy mit jelez az aktuális hírcsatorna.

Magam, könyvtárosként, azaz trendfigyelő emberként (mert a könyvtáros azért a bölcsebb fajtából való, ugyan a társadalom, legalábbis anyagiakban nemigen sorol előkelő helyre minket, de ezt a tényt még maga is elismeri, és szerencsére a bölcsesség sohasem a darabra leszámolható tudás, a bölcsesség a jövőbelátás képessége, a jövő pedig a trendekben van megírva) nagy dilemmában vagyok, hiszen pontosan tudom, az épülő smart világ szenzorok millióit fogja éppen abból a célból elhelyezni a környezetemben, hogy tapintásom helyett tapintson, szemem helyett lásson, fülem helyett halljon, idegvégződéseim helyett jelezzen. Aztán a szenzoradatok millióiból álló felhők mögött látom már azt a szuperszámítógépet, vagy inkább hálózatot, mely az adatokat előrejelzésekké, trendekké formálja, s a végén kidobja, mondjuk éppen a mai ebédem számomra optimalizált menüjét: csirkecomb Hortobágy módra, ami jelenthet, mondjuk egy darab főtt csirkecombot az 1920-as években, a hortobágyi homokon futtatott kakas kukorékolásával, hogy ne csak a gyomrom, a pszichém is épülhessen, természetesen a lelkemet is követő szenzor adatok kiértékelése által elrendelt módon.

De ha a szenzorok mindent megfigyelnek helyettem, ha helyettem gondolkoznak, ha helyettem jeleznek, és a trendet is felállítják, nekem akkor mi marad? Én mit figyelhetek meg? Hol lesz az én helyem a jövő világában?

Nos, ezek már éppen olyan kérdések, amelyek engem is foglalkoztathatnak. S ha foglalkoztatnak, hát választ keresek, s ha válaszokat keresek, hova is fordulhatnék, ha nem a könyvekhez. Ilyenkor le kell emelni a polcról - érzem a késztetést - az első számú trendkutató, trendbemutató könyvet. Amit hordoztak, alakítottak, majd leírtak vagy négyezer éven át, sajnos bő kétezer éve már inkább csak értelmezik, pedig éppen írni nem volna haszontalan, mert az író ember alkot, míg az értelmező csak magyaráz, ami viszont az urak huncutsága. Nos, azt a könyvet, aminek a címét (megnevezését) egészen biztosan mindenki ismeri: Biblia. Jó könyv. Szerethető. Benne van ám minden a jövőről. Én egészen pontosan a Szent István Társulat, az Apostoli Szentszék Könyvkiadója gondozásában 1979-ben megjelent Ószövetségi és Újszövetségi Szentírást szoktam forgatni. 
Az igét olvasva áthat engem az üzenet: ha követsz engem, (mármint az Urat), akkor eljuthatsz valahova. Az ígéret földjére. A jövőbe. Az örök életre.

De ha a boldogságmondásokat olvassuk Máté evangéliumából, azok is arról szólnak, válj valamivé (ami még nem vagy), alakulj át, tégy meg valamit, s elnyersz valamit, a boldogságot. Az ember szolgálata, az emberközpontú tudomány értelme sem lehet más, mint a legfontosabb gyógyító erő, és egyben a legcsodálatosabb emberi érzés, a boldogság szolgálata. „Boldogok a lélekben szegények, mert övék a mennyek országa.” (Mt 5,3) Egyszerűsítsd le a lelkedet, dobd el a dühöt, az akaratosságot, a „mindenáron akarom”-ot, a görcsös ragaszkodást a tárgyakhoz, a büszkeséget, s minden egyéb hívságot (ki-ki a maga jelleme szerint sorolhatja őket), helyettük tárj fel egyetlen egyet, a szeretetedet, a szeretetet adó képességed és ezt áraszd szét önmagadban és tiéd lesz a mennyek országa, azaz a boldogság földje.

„Boldogok, akik ébezile és szomjazzák az igazságot, mert majd eltelnek vele”. (Mt 5,6) Könyvtáros etikánk alapját mondja ki, s egyben értelmét üzeni ez az útmutatás. Hiszen nekünk valóban éheznünk és szomjaznunk kell az igazságot, keresni és megtalálni magunkban, az általunk alkotott lenyomatokban, papírokon, képekben, hangokban, a bináris kódokban és bármilyen egyéb formában is. S ha elűzzük éhünket, s oltjuk szomjunkat, akkor eltelünk. A boldogság eltölt. A boldogság pedig azért csodálatos, mert átadható. Szüksége van a társadalomnak a boldog emberekre! Itt, ma, Magyarországon, és holnap is és azt követően is boldog emberekre van szükség, akik boldogságuk okán maradnak e honban és építik jövőjét. A könyvtárosság, a könyvtáros lét legalapvetőbb küldetése a boldogság megélése és átadása, korlátlan terjesztése 7/24-es üzemmódban, bárki számára, bármilyen hátránnyal küzdő számára, azonos eséllyel. Mert boldogságra, míg ember él a Földön, mindig „szükség” lesz! Mi más ez, ha nem az a trend, amely jövőnk, szakmánk jövőjének értelmét és szükségességét alátámasztja, igazolja nekünk. Bizonyos ismérvek szerint megjósolható, sôt biztosan állítható jövőt láttatván!

Persze a Biblia arról is szól, hogy eljön a világvége, az apokalipszis, s ez bizonyos értelemben nem túlságosan biztató, pontosabban eléggé fenyegető. De a Biblia azt is megmutatja, hogy te, mi, a rettenet pillanatait hogyan kerülhetjük el. Hogyan, miképpen lehetünk éppen mi azok a Noék, akik bárkához jutnak a túléléshez.

A tudomány és a tudás sajátos emberi viszonyáról a Biblia bölcsességén túl számomra Mikszáth Kálmán (1847-1910) nyújtja a mindennapi élethelyzetet leginkább láttató ismeretet. A „tekintetes úr”, aki éppen 170 esztendeje született, meghalni pedig nem méltóztatott, mert a nógrádi tájba úgy belopta magát, hogy onnan és a magyar emberek szívéből eddig legalábbis nem volt erő, mi kipöndörítse. De hát, szerencsére maga sem igyekszik, jelen van velünk tanításaival. Ő írt egy előszó írására szóló felkérés kapcsán egy rövid, de annál tanulságosabb történetet Strázsa János kovácsmesterről, a kiváló megfigyelőről, ,,kinek a keze olyan könnyú volt, mint a hab, úgy hogy a legcsodálatosabb szemoperácziókat tudta végezni olyan ügyesen, hogy a híre elszárnyalt egész Kassáig-Pestig. Különösen a zöld hályogot tudta megoperálni, melyet pedig az akkor hí- 


\section{FEHÉr MiKLÓs}

res Lippay sem tudott." S hogy Lippay professzor a bécsi kollégáit elkápráztassa, Pestre kérette őket, ahova addigra megérkezett a kovácsmester is.

„Hát nézze, Strázsa barátom, ez a betege - mondá Lippay.”

Strázsa uram a vizsgálatot követően „levetette a mándliját, s különböző bicskákat kezdett kiszedegetni a csizmaszárából, meg visszarakosgatni, míg végre kiválasztott egyet és megfente e nadrágszíja lefityegő részén.

- Az isten szerelméért! - kiáltá ijedten Lippay. - Csak nem ezzel a békanyúzó bicsakkal akarja operálni?

A kovács csak a szemöldökével intett, hogy igenis azzal. Lippay az asztalon heverő szerszámok közül hirtelen kiválasztott egy Graefe-féle kést s a markába nyomta.

- Nem, - mondá fitymálva Strázsa uram - ezzel nem lehet.

Ellökte a Graefe-kést és a magáéval lépett a szepegő szabóhoz, mire egyet villan a kés pengéje, s mintha csak almát hámozna, játszi könnyedséggel siklott el a szemgolyón; egy pillanat, egy villanás, és ime, lent volt a hályog." A sikeres mútétet követően Lippay professor fortyant fel haragosan.

- „Hallja, Strázsa, maga mégis rettenetes vakmerő ember! Tudja-e, mivel játszik? Tudja-e, hol vagdalt, mit vagdalt? Tudja-e, milyen felelősséget vállal isten és emberek előtt? Tudja-e, mi az a szemhártya, érhártya, ideghártya, könnytömlő és a többi?

- Minek tudnám, kérem alássan?”

Csak azért, mert „ha csak egy gondolattal vág odább jobbra vagy balra, a másik szemnek is kioltja a világát!"

Strázsa János bizony „azontúl, hogy megtudta, milyen komplikált külön világ a szem, s mennyi veszély származhatik kezének parányi rezzenéséből, vérének sebesebb lüktetéséből, késének egy gondolatnyi elsiklásából, soha többé nem mert hályogot operálni, sőt még egy árpa kigyógyításába sem bocsátkozott."*

Mikszáthtól okulván megalkottam a követendő trendet: meg kell maradnunk megfigyelőnek! S ne engedjük, hogy a tudomány roppant súlyának a hiánya, vagy éppen megléte kettétörje életünket. Végezzük szaporán és lelkesen a magunk megfigyeléseit, maradjunk meg életünk végéig tanuló kisgyermeknek. És ne hagyjuk, bármennyire is ebbe az irányba haladunk, hogy mindent szenzorokkal, szenzor adatokkal írjunk le, hogy mindent a számítógép értékeljen ki, hacsak nem akarunk csirkelábat enni instant kakaskukorékolással.

Végezetül az 1. táblázatban teszem közzé előadásom lényegének kibontását, amelyet a Könyvtári Intézet a maga számára kijelölt „kovász szerep” sikeres betöltése érdekében vetett papírra 2017 őszén. Ebben 11 célcsoportot, célcsoport elvárásokat és elvégzendő feladatokat határoztunk meg. A megvalósításon dolgozunk.

* Forrásdokumentum: MIKSZÁTH Kálmán: Mikor a mécses már csak pislog. Elbeszélések. Budapest, Révai, 1906. (Mikszáth Kálmán munkái). Az elbeszélés címe: A hályog-kovács. Egy kis életkép. 


\section{1. táblázat}

\section{A Könyvtári Intézet feladatai az egyes célcsoportok elvárásai szerint}

\begin{tabular}{|c|c|c|}
\hline Célcsoport & $\begin{array}{l}\text { Az érintett célcsoport leg- } \\
\text { fontosabb elvárásai }\end{array}$ & $\begin{array}{l}\text { Az elvárások teljesítése érdekében } \\
\text { végzendő kiemelt tevékenységek }\end{array}$ \\
\hline \multirow[b]{2}{*}{$\begin{array}{l}\text { A hazai } \\
\text { társadalom }\end{array}$} & $\begin{array}{l}\text { Valós ismeretek a magyar könyv- } \\
\text { tári rendszerrôl. }\end{array}$ & $\begin{array}{l}\text { Országjelentések közreadása, hírek generá- } \\
\text { lása a TV, rádió, a nyomtatott és elektroni- } \\
\text { kus média számára. }\end{array}$ \\
\hline & $\begin{array}{l}\text { A könyvtárak és a könyvtári } \\
\text { rendszer legyen felhasználó- } \\
\text { barát, szolgáltatásai legyenek } \\
\text { frissek, érdekesek, személyre } \\
\text { szabottak és egyben esély- } \\
\text { egyenlőséget megteremtők, } \\
\text { családbarátok. }\end{array}$ & $\begin{array}{l}\text { A könyvtári rendszer, a könyvtárak támo- } \\
\text { gatása a könyvtárhasználati kedv fokozása } \\
\text { érdekében. A könyvtárak társadalmi sze- } \\
\text { repvállalásának erôsítése. A lakosságnak és } \\
\text { az egyes felhasználói csoportoknak kínált } \\
\text { szolgáltatások (pl. könyvtárajánló, speciális } \\
\text { könyvtári szolgáltatások speciális helyzet- } \\
\text { ben élőknek, konyvtarak.hu stb.). }\end{array}$ \\
\hline \multirow[t]{2}{*}{$\begin{array}{l}\text { A nemzetközi } \\
\text { szakma }\end{array}$} & $\begin{array}{l}\text { Ismeretek a magyar könyvtári } \\
\text { rendszerről, a megvalósult fej- } \\
\text { lesztésekről, jó gyakorlatokról, } \\
\text { angol nyelven elérhető statisz- } \\
\text { tikai forrásokból. }\end{array}$ & $\begin{array}{l}\text { Kutatási eredmények nemzetközi lapok- } \\
\text { ban és konferenciákon történő bemutatása. } \\
\text { Nemzetközi szervezetekben való tagság. } \\
\text { Személyes jelenlét nemzetközi értekezlete- } \\
\text { ken és konferenciákon. Kétnyelvű statiszti- } \\
\text { ka közreadása. }\end{array}$ \\
\hline & $\begin{array}{l}\text { Partnerség kutatások, vizs- } \\
\text { gálatok végzésében (pl. ALM- } \\
\text { PUB). }\end{array}$ & $\begin{array}{l}\text { Együttmúködés projektcélok megvalósításá- } \\
\text { ban (elsősorban kutatási tevékenység, össze- } \\
\text { hasonlító vizsgálatok, elemzések végzése). }\end{array}$ \\
\hline \multirow{4}{*}{$\begin{array}{l}\text { A hazai } \\
\text { könyvtárosok }\end{array}$} & $\begin{array}{l}\text { Legyen egy „hely”, ahova for- } \\
\text { dulni lehet a szakmai kérdések- } \\
\text { ben. }\end{array}$ & $\begin{array}{l}\text { Módszertani támogatás megjelenítése és } \\
7 / 24 \text { múködtetése az intézeti honlapon. }\end{array}$ \\
\hline & $\begin{array}{l}\text { Hívja fel a figyelmet progra- } \\
\text { mokra, eseményekre, képzési } \\
\text { lehetôségekre. }\end{array}$ & $\begin{array}{l}\text { Rendezvénynaptár, éves képzési terv köz- } \\
\text { readása, képzési tartalmak folyamatos fris- } \\
\text { sítése. }\end{array}$ \\
\hline & $\begin{array}{l}\text { A KI kommunikáljon érdem- } \\
\text { ben a könyvtárosok, könyv- } \\
\text { tárak, könyvtárszakma, az ol- } \\
\text { vasás és a könyvtárhasználat } \\
\text { társadalmi megbecsüléséért. }\end{array}$ & $\begin{array}{l}\text { Releváns információk a könyvtárhasználat- } \\
\text { ról, az olvasás népszerúségérôl, az ezzel kap- } \\
\text { csolatos jó gyakorlatokról. Általános és in- } \\
\text { tenzív marketing és PR tevékenység végzése. }\end{array}$ \\
\hline & $\begin{array}{l}\text { Útmutatás a könyvtár egysé- } \\
\text { ges, minőségelvű múködése } \\
\text { kialakításához. }\end{array}$ & $\begin{array}{l}\text { Módszertani támogatás, segédanyagok pub- } \\
\text { likálása, a minősítési rendszer folyamatos } \\
\text { fejlesztése. }\end{array}$ \\
\hline
\end{tabular}




\begin{tabular}{|c|c|c|}
\hline \multirow{2}{*}{$\begin{array}{c}\text { A határon } \\
\text { túli magyar } \\
\text { könyvtárosok }\end{array}$} & $\begin{array}{l}\text { Bekapcsolódni a magyar könyv- } \\
\text { táros (tovább)képzés rendsze- } \\
\text { rébe. Ismeretek gyarapítása, jó } \\
\text { gyakorlatok átvétele. }\end{array}$ & $\begin{array}{l}\text { Képzésszervezés, képzések lebonyolítása, } \\
\text { blended learning és e-learning képzések be- } \\
\text { vezetése, múhelynapok, előadások, tájékoz- } \\
\text { tatók tartása, szervezése. }\end{array}$ \\
\hline & $\begin{array}{l}\text { Határon túli eredmények, si- } \\
\text { kerek, valamint problémák, } \\
\text { nehézségek láttatása Magyar- } \\
\text { országon. }\end{array}$ & $\begin{array}{l}\text { Szakfolyóirat kiadása, webes információszol- } \\
\text { gáltatás, szakreferensi rendszer kidolgozása. }\end{array}$ \\
\hline \multirow{4}{*}{$\begin{array}{l}\text { A közkönyv- } \\
\text { tárak }\end{array}$} & Munkatársak (tovább)képzése. & $\begin{array}{l}\text { A könyvtári terület szakképzési tartalmának } \\
\text { megújitása, országos koordinációs központi } \\
\text { és vizsgaszervezői szerep ellátása. Tovább- } \\
\text { képzések akkreditálása. }\end{array}$ \\
\hline & $\begin{array}{l}\text { Módszertani támogatás nyújtá- } \\
\text { sa a települési könyvtári ellátás } \\
\text { teljes vertikumára vonatkozó- } \\
\text { an, ide értve a KSZR rendszer } \\
\text { múködésének támogatását. }\end{array}$ & $\begin{array}{l}\text { Módszertani konzultáció biztosítása, mun- } \\
\text { kacsoport tevékenység, jó gyakorlatok köz- } \\
\text { vetítése, minőségi szempontok szerinti mű- } \\
\text { ködés támogatása, innováció támogatás. }\end{array}$ \\
\hline & $\begin{array}{l}\text { Országos és regionális elemzé- } \\
\text { sek, trendek közreadása. }\end{array}$ & $\begin{array}{l}\text { Nyilvános könyvtári tevékenységgel kap- } \\
\text { csolatos információ megosztás - hazai és } \\
\text { külföldi témafigyelés. }\end{array}$ \\
\hline & $\begin{array}{l}\text { Hazai és nemzetközi gyakor- } \\
\text { latok, innovációk, jó példák, } \\
\text { szakmai kérdések, események } \\
\text { bemutatása. }\end{array}$ & $\begin{array}{l}\text { Múhelynapok tartása, kommunikációs fe- } \\
\text { lületek müködtetése, szakmai kiadványok } \\
\text { megjelentetése. }\end{array}$ \\
\hline \multirow{3}{*}{$\begin{array}{l}\text { A szak- és } \\
\text { tudományos } \\
\text { könyvtárak }\end{array}$} & $\begin{array}{l}\text { A tudományos és szakkönyv- } \\
\text { tári tevékenységek támogatása. }\end{array}$ & $\begin{array}{l}\text { Fórumok szervezése, útmutatók, szabályo- } \\
\text { zók, szabványok közreadása. }\end{array}$ \\
\hline & ODR együttmúködés & $\begin{array}{l}\text { A Könyvtártudományi Szakkönyvtár mú- } \\
\text { ködtetése, a szakkönyvtári partnerkapcsola- } \\
\text { tok ápolása. }\end{array}$ \\
\hline & $\begin{array}{l}\text { Hazai és nemzetközi szakmai } \\
\text { ismeretek közvetítése, valamint } \\
\text { publikálási lehetôség biztosítása. }\end{array}$ & $\begin{array}{l}\text { A Könyvtári Figyelő kiadása, hazai és kül- } \\
\text { földi témafigyelés, referálás. }\end{array}$ \\
\hline \multirow[t]{2}{*}{$\begin{array}{c}\text { A } \\
\text { felsőoktatási } \\
\text { könyvtárak }\end{array}$} & $\begin{array}{l}\text { Módszertani támogatás köz- } \\
\text { ponti fejlesztések megvaló- } \\
\text { sításához (pl. a gyújtemény } \\
\text { közoktatási célú digitalizá- } \\
\text { lása, tematikus ismeretanyag } \\
\text { összeállítása). }\end{array}$ & $\begin{array}{l}\text { Módszertan, módszertanhoz kapcsolódó } \\
\text { tudástár kialakítása, igények, elvárások köz- } \\
\text { vetítése, kompetenciafejlesztés, képzés. }\end{array}$ \\
\hline & $\begin{array}{l}\text { Információ a tudományos infor- } \\
\text { mációszolgáltatás témakörben. }\end{array}$ & Szakterületi tájékoztató feladatok ellátása. \\
\hline
\end{tabular}




\begin{tabular}{|c|c|c|}
\hline & $\begin{array}{l}\text { Támogatás a célcsoport tevé- } \\
\text { kenységének elemzéséhez. }\end{array}$ & $\begin{array}{l}\text { Elemzések, értékelések, kutatások a tudo- } \\
\text { mányos és szakkönyvtári tevékenységről. }\end{array}$ \\
\hline & Munkatársak (tovább)képzése. & $\begin{array}{l}\text { Új képzési programok engedélyeztetése, kép- } \\
\text { zésszervezés, lebonyolítás, blended learning } \\
\text { és e-learning képzések bevezetése. }\end{array}$ \\
\hline \multirow{3}{*}{$\begin{array}{l}\text { Az egyházi } \\
\text { könyvtárak }\end{array}$} & $\begin{array}{l}\text { Információk, útmutatók, eljá- } \\
\text { rások. }\end{array}$ & $\begin{array}{l}\text { Fórumok szervezése, útmutatók, szabályo- } \\
\text { zók, szabványok közreadása. Szakterületi } \\
\text { információ-megosztás, hazai és külföldi té- } \\
\text { mafigyelés. }\end{array}$ \\
\hline & $\begin{array}{l}\text { Támogatás a célcsoport tevé- } \\
\text { kenységének elemzéséhez. }\end{array}$ & $\begin{array}{l}\text { Elemzések, kutatások az egyházi könyvtári } \\
\text { tevékenységrőll, a könyvtárak helyzetéről, } \\
\text { gyúiteményrôl. }\end{array}$ \\
\hline & $\begin{array}{l}\text { A munkatársak (tovább)kép- } \\
\text { zése. }\end{array}$ & $\begin{array}{l}\text { Speciális programok engedélyeztetése, kép- } \\
\text { zésszervezés, lebonyolítás, blended learning } \\
\text { és e-learning képzések. }\end{array}$ \\
\hline \multirow{2}{*}{$\begin{array}{l}\text { A kulturális } \\
\text { alapellátás } \\
\text { társszereplői }\end{array}$} & $\begin{array}{l}\text { A szakterületek közötti pro- } \\
\text { jektek (pl. CSK, Az én könyv- } \\
\text { táram) megvalósításában a KI } \\
\text { rugalmas partner legyen. }\end{array}$ & $\begin{array}{l}\text { Projektszervezet múködtetése, projektfel- } \\
\text { adatok rugalmas ellátása. }\end{array}$ \\
\hline & $\begin{array}{l}\text { A KI közvetítse a partnerek felé } \\
\text { a könyvtári szakterület projekt } \\
\text { szempontból releváns informá- } \\
\text { cióit. }\end{array}$ & $\begin{array}{l}\text { A könyvtári szakterület képviselete rendez- } \\
\text { vényeken és képzéseken. }\end{array}$ \\
\hline \multirow{5}{*}{ A fenntartó } & $\begin{array}{l}\text { A jogszabályból eredő felada- } \\
\text { tok egyenletesen magas szín- } \\
\text { vonalon történő ellátása. }\end{array}$ & $\begin{array}{l}\text { A KI-munkafolyamatok minőségbiztosítá- } \\
\text { sa. }\end{array}$ \\
\hline & $\begin{array}{l}\text { Pontos és megbízható háttér- } \\
\text { adatbázisok múködtetése. }\end{array}$ & $\begin{array}{l}\text { Adatbázisok rendszeres felülvizsgálata, } \\
\text { pontosítása, honlapon való közzététel. }\end{array}$ \\
\hline & Szakmai döntések támogatása. & $\begin{array}{l}\text { Rendszeres konzultáció a fenntartóval, a } \\
\text { stratégiai irányok támogatása informatikai } \\
\text { megoldásokkal, melyek mind a fenntartó, } \\
\text { mind a felhasználó könyvtárak igényeit fi- } \\
\text { gyelembe veszik. }\end{array}$ \\
\hline & $\begin{array}{l}\text { Elemzések, dokumentációk, } \\
\text { háttéranyagok készítése. }\end{array}$ & $\begin{array}{l}\text { Tájékozódás, tájékoztatás, kapcsolattartás, } \\
\text { az ebből eredő információk megosztása. }\end{array}$ \\
\hline & $\begin{array}{l}\text { Alkalmasság (delegálhatóság) } \\
\text { hazai és nemzetközi (pilot) } \\
\text { projektek lebonyolítására. }\end{array}$ & $\begin{array}{l}\text { Gazdag kompetencia-készlet fenntartása a } \\
\text { gyorsaság és a projektekbe történő rugalmas } \\
\text { bekapcsolódás érdekében. }\end{array}$ \\
\hline
\end{tabular}




\begin{tabular}{|c|c|c|}
\hline \multirow{4}{*}{ Az OSZK } & $\begin{array}{l}\text { Részvétel nemzetközi és hazai } \\
\text { programokban. }\end{array}$ & $\begin{array}{l}\text { Munkacsoportokban, projektmunkákban való } \\
\text { részvétel. }\end{array}$ \\
\hline & $\begin{array}{l}\text { Az OSZK folyamatok kontroll- } \\
\text { jában, minőségbiztosításában } \\
\text { való közreműködés. }\end{array}$ & $\begin{array}{l}\text { Közremúködés belső mérések, elemzések } \\
\text { készítésében. }\end{array}$ \\
\hline & $\begin{array}{l}\text { A szakmai berkekben megje- } \\
\text { lenő, OSZK-t érintő kérdések } \\
\text { közvetítése. }\end{array}$ & $\begin{array}{l}\text { Rendszeres konzultáció az OSZK igazgató- } \\
\text { ságaival. }\end{array}$ \\
\hline & $\begin{array}{l}\text { Általános könyvtárszakmai } \\
\text { alapelvek disszeminálása, képvi- } \\
\text { selete a könyvtári rendszer felé. }\end{array}$ & $\begin{array}{l}\text { Fórumok szervezése, kiadványok megjelen- } \\
\text { tetése, műhelymunka, tájékoztatás. }\end{array}$ \\
\hline $\begin{array}{l}\text { A szakmai } \\
\text { szervezetek }\end{array}$ & $\begin{array}{l}\text { Közös szakmai programok, is- } \\
\text { meretek gyarapítása, jó gyakor- } \\
\text { latok közvetítése, trend infor- } \\
\text { mációk. }\end{array}$ & $\begin{array}{l}\text { A szakma, a célcsoport és a társadalom kap- } \\
\text { csolatát, bizalmát, identitását támogató tevé- } \\
\text { kenység segitése adatforrásokkal, folyóirat, } \\
\text { honlap és közösségi médiafelület megosztással. }\end{array}$ \\
\hline
\end{tabular}

Fehér Miklós könyvtáros, magyar - ének-zene szakos tanár. 1993-tól 1999-ig Salgótarjánban megyei könyvtár igazgató. 1999-2001 között a Fővárosi Szabó Ervin Könyvtár Központi Könyvtár igazgatója. 2001-től jelenlegi munkahelyén, az Országos Széchényi Könyvtárban működő Könyvtári Intézetben dolgozik, ahol jelenleg igazgató. 